\title{
Tourism tax levies - the municipal perspective: Tourism tax levies in the city of Timmins
}

\begin{abstract}
Christy Marinig, Ec.D.
The City of Timmins has expressed interest in examining the relative impact of imposing a hotel tax also known as a visitor tax or tourism levy. There are a number of key issues facing tourism marketing and attraction development in the City of Timmins. The issues surrounding the hotel tax and its potential for positive economic returns have been the subject of considerable debate. This paper examines the pros and cons of the tax and concludes that it is time for the provincial government to work in partnership with the local governments and grant the right to impose such a tax. The author argues this would provide municipalities with the ability to raise revenues which could then be employed to stimulate further local economic growth.
\end{abstract}

Keywords: tourism, tax levies, partnership, Northern Ontario, municipal government

\section{Introduction}

The City of Timmins has expressed interest in examining the relative impact of imposing a hotel tax also known as a visitor tax or tourism levy. There are a number of key issues facing tourism marketing and attraction development in the City of Timmins. The issues surrounding the hotel tax and its potential for positive economic returns have been the subject of considerable debate. Based on the research that is available, it is obvious that a sound taxation model is needed to succeed. Research has also shown that with proper planning and management, hotel taxes can provide a stable source of income to carry out tourism initiatives in the City of Timmins.

The City of Timmins is located in Northern Ontario. The community is approximately 680 kilometres from the City of Toronto. Access to the community is available through road, rail or air passenger services. Timmins is located $42 \mathrm{~km}$ from the Trans-Canada highway and is accessible by Highways 101 and 144. Tourism Timmins is the organizing body that coordinates tourism marketing, conventions and attraction development for the community. This organization is comprised of municipal staff; however, a strong private and public sector subcommittee of the Timmins Economic Development Corporation (TEDC) does work in partnership with Tourism Timmins to generate additional tourism activities and events within the municipality.

The community is a regional centre with a base population of approximately 48,000 residents. The main trading area encompasses approximately 117,000 people. It extends throughout the 
Cochrane District and to the James Bay coastal areas. Several other communities such as Chapleau and Kirkland Lake have also been added to the market area demographic profile. The central location has allowed the city to become a regional shopping, cultural, commerce, health, industrial supply and distribution centre for Northeastern Ontario. The regional airport serves over 160,000 passengers annually and has six connecting flights to and from Pearson International Airport (Toronto) on a daily basis.

There are a number of local attractions available for tourists throughout the year. Some of the key attractions within the city limits include the Timmins Underground Gold Mine Tour, the Shania Twain Centre, Cedar Meadows Resort and Wildlife Park, and the Timmins Museum: National Exhibition Centre. In the summer additional industry related tours are offered including: the Falconbridge Kidd Creek Metallurgical Site Tour, Domtar Lumber Tour, Tembec Inc. Sawmill Tour, and the Millson Forestry Forest Regeneration Nursery Tour. Timmins is also a popular tourist destination for anglers/hunters and snowmobile enthusiasts.

According to the majority of local hotel managers, the primary market for the hotel sector in the community is comprised of business travellers. They are estimated to make-up 65 per cent of the accommodations market. The tournament and special events market makes up 30 per cent and leisure travellers' account for approximately five per cent of the market share. It is quite obvious that if the community wants to pursue tourism as a key economic generator they need to focus their efforts on pursuing the leisure market. ${ }^{1}$

A community strategic plan was recently completed and tourism development was identified as a primary goal for the municipality. In order to pursue these key tourism initiatives it is critical that the attractions and accommodations providers begin collecting meaningful data on tourists who visit the community. Tourism Timmins is working in partnership with the hotels and the attraction centres to develop a unified survey mechanism to help them define their target markets and ensure that the community offers attractions that meet consumer demands. It is also imperative that the community allocate proper resources and encourage private sector development to capitalize on tourism opportunities.

\section{Current situation}

Based on the 1999 Canadian Travel Survey and the 1999 International Travel Survey from Statistics Canada, a total of 1,001,000 visitors travelled into the James Bay Frontier (JBF) region. The City of Timmins is located in this region and is known as the largest centre of the region. Of the million visitors to the JBF region the breakdown is as follows: 872,000 from Ontario, 69,000 US visitors, 52,000 from other provinces and the balance from other countries. The region experiences the lowest number of visitors in all of the Ontario travel zones. This could be due to

\footnotetext{
${ }^{1}$ Interview with Timmins Accommodations Group (TAG) committee members, May 2001.
} 
a number of reasons such as: distance to the market, unfocused advertising/marketing of products, tourism products offered may not meet consumer demands and/or aggressive competition from other Ontario markets. Tourism expenditures in the region were as follows: $\$ 88.2$ million from Ontarians, $\$ 13.3$ million from residents of the US, $\$ 8.2$ million from other Canadians and \$2.3 million from tourists from other countries (Ontario Ministry of Tourism Culture and Recreation - OMTCR, 2001).

According to the Ontario Ministry of Tourism, Culture and Recreation, Tourism Regional Impact Model (TREIM), the Gross Domestic Product of direct and indirect impact has an estimated value of $\$ 108,951,000$ in the JBF region. The tourism industry accounts for 3,553 jobs and is expected to grow in the future. It is impossible to determine the exact numbers for the City of Timmins; however, as noted previously it is the largest community in this tourism zone. It is quite evident that this industry plays a key role in the development of the community. It is time for Timmins to be proactive and to ensure that it implements policies that will help this sector of the economy grow and flourish (OMTCR, 2001).

A key problem facing the tourism industry in the City of Timmins is that until very recently the municipal government has had a limited view of the potential of the industry and as a result, marginal resources have been devoted to developing and promoting the sector. Tourism is still narrowly viewed as tourists and hotels and unless the necessary plans, policies, actions and resources to support the growth of this industry are put into place it will continue to be a missed opportunity.

Tourism represents a significant opportunity for the community. World tourism statistics state that the industry "employs 212 million people worldwide, generating \$3.4 trillion in world gross output and contributing $\$ 655$ billion of Government tax revenues; travel and tourism is the world's largest industry. In Britain, Germany, Japan, and the USA, more adults have traveled than visited a library, attended a sporting event or have gone to see a play or concert. The tourism industry is expected to grow by 50 per cent by 2005 by which time the industry will be worth US\$7 trillion to the world economy (Creamer Media, n.d)."

The World Travel and Tourism Council estimates that travel and tourism is now the world's largest generator of jobs. In 1995, the industry provided direct and indirect employment for 212 million people, accounted for 10.7 per cent of the global work force, and provided one in every nine jobs. Between 1995 and the year 2000 travel and tourism was estimated to have created 125 million new direct and indirect jobs (Creamer Media, n.d).

"The Ontario tourism industry is an important generator of jobs, tax revenues and export dollars. In 1999, the tourism industry accounted for $\$ 16.5$ billion in tourism expenditures, spent by 106.1 million visitors. Tourism provided 254,000 
direct jobs and an additional 172,000 indirect and induced jobs, representing over nine per cent of Ontario's employment. The industry generated $\$ 7.0$ billion in total taxes, of which $\$ 2.4$ billion was provincial tax revenue. Tourism was Ontario's $5^{\text {th }}$ largest export industry, bringing into the province $\$ 7.1$ billion in foreign exchange, up 2.9 per cent over the 1998 figure.

Tourism contributed $\$ 7.2$ billion to provincial Gross Domestic Product in 1999, ahead of agriculture, mining and forestry/logging (OMTCR, 2001)".

Some key benefits of the tourism industry are as follows:

- tourism demand is continuous;

- properly organized and focused, the tourism sector can create many jobs within a short period;

- the tourism industry has the lowest ratio of investment to job creation;

- tourism employs a multiplicity of skills and there are a number of occupations which provide on the job training;

- the tourism industry creates entrepreneurial opportunities;

- tourism brings development to rural as well as urban areas;

- well-managed tourism uses safe environmental practices;

- tourism has a multiplier effect.

Tourism Timmins has never used focused marketing strategies to generate interest in the leisure tourism market. They have always opted for a shotgun approach because the marketing budget is only $\$ 45,000$ per year. They believed it was better to get the message out to various markets rather then focus on very specific initiatives. It is difficult for the municipality to generate excitement and interest in such a competitive industry with such a minimal budget.

Tourism Timmins is also responsible for the creation and on-going expansion of several key attractions in the community such as the Shania Twain Centre, the Gold Mine Tour and the Timmins Museum. The marketing budget for these attractions combined is only about $\$ 60,000$. Until very recently these groups did not always jointly coordinate their marketing efforts and an effective and measurable campaign was never launched. They also realize that it is imperative for them to look at new attractions and on-going expansions of the current sites in order to maintain world-class facilities while offering new products to their target markets. 
There are approximately 710 hotel/motel rooms in the City of Timmins. The average annual occupancy rate is approximately 62 per cent, and at the current time there are no real plans to add additional rooms to the inventory. ${ }^{2}$

\section{Key barriers to tourism development in Timmins and proposed solutions}

The availability of resources to develop and promote the tourism industry in the City of Timmins is critically important for the industry's further growth and development.

A number of policy guidelines should be implemented to guide the increased financial commitment to the development of tourism in the community. While the exact nature and extent of these should be properly assessed and evaluated, the following measures should be considered:

- ensure that there are accurate and detailed statistics about visitors;

- ensure support for attractions and developments that are appealing to target markets ;

- conduct a review of available public (federal, provincial and municipal) support for tourism;

- look for private and public sector partners to research and develop appropriate attractions and marketing programs;

- investigate and lobby provincial government to secure the right to impose a hotel tax at the municipal level;

- promote partnerships for the provision of funding between and among government agencies (federal and provincial, local) and the private sector.

A central feature of tourism relates directly to the creative marketing and promotion of the community. To be effective, the marketing and promotion of Timmins needs to be a coordinated and structured approach that may include other regional municipalities. Some of the key initiatives include:

- aggressively marketing and promoting tourism to all Ontarians; encouraging citizens to take holidays in their own province since 66 per cent of travellers in the province are Ontarians visiting other communities (OMTCR, 2001);

- marketing and promoting attractions and experiences to visitors who are already in Timmins and encouraging visitors to increase their expenditures locally since 65 per cent of the current market share consists of business travellers who usually spend more per visit than regular tourists; ${ }^{3}$

\footnotetext{
2 Interview with Timmins Accommodations Group (TAG) committee members, May 2001.

${ }^{3}$ Interview with Timmins Accommodations Group (TAG) committee members, May 2001.
} 
- promoting favourable exchange rates when targeting US and overseas consumers; 28 per cent of the Ontario travel market is comprised of US citizens (OMTCR, 2001);

- beyond the domestic leisure market, ongoing emphasis should be placed on other key generating markets, such as tournaments and conventions;

- public relations efforts should be directed at the local market by promoting attractions and sites to local consumers;

- marketing and promotions focused on the well-established sites, as well as new and emerging products and attractions;

- pursuing cooperative advertising and promotion opportunities;

- employing a hotel tax to help offset costs;

- conducting research into the development of new markets and new market niches;

- establishing mechanisms to monitor the effectiveness of promotion expenditures.

Tourism can be an engine of growth, capable of enhancing and rejuvenating other sectors of the economy; however, viable approaches must be explored to generate revenue to support this endeavour.

Hotel taxes are used extensively in the US and some Canadian provinces and cities have started to implement a hotel tax to ensure they have a stable source of revenue for their marketing and capital project programs. Currently in Ontario the provincial government has not implemented legislation to permit municipalities to impose hotel taxes in their communities. Several large urban centres like Toronto and Ottawa have been working diligently for change in legislation, so they can compete more effectively on an international level.

In Ontario current taxes charged by the hotel sector include the retail sales tax, which is a consumption tax and is based on the retail price of most goods. Currently most lodging as provided by hotels, motels and lodges is taxable at five per cent.

The majority of goods and services sold or provided in Canada are subject to the GST currently at seven per cent. Consumers who stay in Ontario hotels currently pay 12 per cent in taxes.

\section{Taxation principles}

"Taxes act as a wedge between the price paid by the consumers and the price received by suppliers. The imposition of a tax will shift quantity demanded from the original market equilibrium to the post tax quantity (World Travel \& Tourism Tax Policy Center -WTTTPC, 2001).”

When consumers are price sensitive suppliers are often forced to absorb the new tax; however, if suppliers are price sensitive the tax will be passed onto the consumer. 
"Travel \& Tourism is unlike most conventional markets. In conventional markets, consumers are fixed and products are mobile. In Travel \& Tourism markets, consumers are mobile and the products are fixed. Policies relating to Travel \& Tourism often fail to reflect that it is a competitive exporting industry.

In most cases, the revenues from exports are recaptured when products are shipped to outside destinations. In Travel \& Tourism, export revenues are captured when travelers arrive at the destination (WTTTPC, 2001)."

"Governments rely on an array of taxes and other fees to generate funds, or to modify behaviour. Taxation, depending on its design and application, can also act to stimulate or dampen economic activity in specific sectors.

Although sector-specific taxes are normally created with good intent, as a means to create revenue and possibly stimulate economic activity, the total effects of these taxes are often not felt in the short-term, and negative repercussions can result (WTTTPC, 2001)."

A World Tourism Taxation Centre study of taxation policy by the London School of Economics has produced five basic economic principles that should be applied to the design of taxes and user charges for all industries, including Travel \& Tourism (WTTTPC, 2001). The five principles include equity, efficiency, simplicity, fair revenue generation and effective stimulus to growth.

\section{Equity}

All economies should be treated fairly in regards to taxation. Even-handed treatment reduces imbalances that can result in political, social and economic difficulties.

\section{Efficiency}

Taxes must generate revenue without creating a significant impact on the demand for a good or service (unless tax is designed to modify behaviour). At a certain threshold, the revenue gained from a tax increase can be lost because of reduced demand. Even more, the decrease in demand sends a debilitating wave throughout the economy as suppliers are affected. The negative impact swells, because of the subsequent loss of tax revenue in many sectors.

\section{Simplicity}

Complicated taxing schemes eat up revenues through administrative costs. These costs include both those borne by government in the process of collecting and enforcing taxes, and those borne 
by taxpayers. One objective of good tax policy is to achieve the highest possible ratio of revenues generated per dollar invested in collecting the tax.

Special note should be made to consider the taxpayers' costs of compliance in calculating this ratio. Simplicity in taxing also dictates that governments should make it clear what the tax rates are, and how the revenues are to be used.

\section{Fair revenue generation}

Fair revenue generation arises from the concept of equity. In the even-handed capturing of tax revenue, it is unreasonable to assess special fees or levy on specific goods or services. These types of taxes are often cloaked by language and terminology to hide their real intent. Although special charges and fees may appear at face value to be modest, they can quickly accumulate and become an unreasonable burden to a sector.

\section{Effective stimulus to growth}

Tax incentives and disincentives should be imposed with the underlying goal of stimulating growth. Taxes that support infrastructure will ideally result in the attraction of investment and new employment. However, when taxes become excessive, economic growth often grinds to a halt.

\section{Key points to ensure that the city of Timmins meets intelligent taxation principles}

- it must compare its current tax structure against main competitors and conduct a review of current prices for accommodations to ensure competitiveness;

- ensure that growth of the tourism sector is regarded as the key priority when devising and implementing such a tax;

- ensure that local tourism stakeholders actively participate in the formulation of policies effecting the industry;

- design a policy that does not inhibit the competitiveness and vitality of the industry;

- ensure that the policy is consistent with fiscal policy and the economic goals of the federal, provincial and municipal governments;

- ensure that the system used to collect taxes is simple and easy to administer so that the cost to government or industry does not increase;

- assess the impact of the taxes on the community and industry. 


\section{Key points to policy development}

"Policy is defined as a plan or course of action, of a government, political party, or business, intended to influence and determine decisions, and other matters." ${ }^{4}$

Policies are important because they are the foundation of the operation and they streamline processes to ensure that they are effective. Policies need to be clear, concise, fair and responsible in order for them to be accepted. There are several types of polices that exist: regulatory, advisory and informative. A tax levy would be regarded as regulatory policy.

Common components in policy development include the following: statement of policy, authorizing body, author, reference to other polices, measurement of expectations, waiver request, process for requesting change, violation and penalties imposed, policy communication strategy and the date the policy becomes effective. It is imperative that the legislation be worded very carefully to avoid confusion and future legal challenges. It is also critical to ensure that the policy clearly specifies projects which qualify for support from the revenues, as any form of ambiguity will give rise to challenges.

\section{Pro's and con's regarding hotel taxes}

\section{Advantages}

There are a number of advantages in using a tax structure to generate revenues for tourism:

- financial resources are generated locally, and are a stable source of revenue;

- the burden of payment can be directed to non local residents;

- finances generated in this manner can often be used to obtain federal and provincial "matching" dollars for marketing or tourism development projects;

- there is no need to set up a new collection system;

- stakeholders have an active role in deciding how the money should be spent;

- in Timmins the room rates are lower than metropolitan areas and very similar between local establishments so there would be no real issues related to price sensitivity;

- provide funding to develop and implement a marketing strategy designed to increase the community's share of the leisure tourism market;

- enable Tourism Timmins the opportunity to focus on their real role of marketing and attraction development rather than concentrating their efforts on fundraising;

- permit the community to plan for new projects knowing that it has a stable source of revenue;

\footnotetext{
${ }^{4}$ Britannica.com, Merriam-Webster Search, Collegiate Dictionary.
} 
- $\quad$ support for the tax by industry knowing that revenues will be allocated to marketing and tourism development projects;

- tax revenues will support growth in tourism activity which in turn will generate added tax revenues;

- the imposition of a tax ensures that all accommodation providers are treated equally;

- in view of downloading by the province, this legislation provides communities the opportunity for gaining funding for specific projects.

As described below a hotel tax can represent a secure source of funding to supplement marketing programs. In the Canadian examples all of the cities that have implemented a hotel tax have not seen a decrease in their tourism visitors and or expenditures. In fact, they have all experienced growth in the tourism sector. Furthermore, in some jurisdictions tax revenue dollars are used for capital projects that help promote tourism activity. In some US states the amount of tax revenues collected are extremely lucrative and help to construct major projects like major league sports arenas.

\section{Some examples}

"In Canada currently Montreal and Laval, Quebec, Vancouver, British Columbia and St. John's, Newfoundland all charge a three per cent hotel tax. In all locations the number of visitors and the dollars spent in these areas has grown even with the inception of the tax (The Economic Planning Group of Canada, 1998)."

"Olathe, Kansas has an incentive plan for raising the hotel tax from four to six per cent. The tax increase generates $\$ 200,000$ per year (Cooper, 2001)."

"The Greater Kansas City Convention and Visitors Bureau and the Hotel and Motel Association of Greater Kansas City asked voters to support a one per cent increase to their tourism levy. Going from 5.5 to 6.5 per cent this increase was expected to generate about an additional \$2.3 million annually (Horsely, 2001).”

"St. Louis Country could use the money from its hotel tax to help finance the construction of a new stadium for the St. Louis Cardinals. Currently the county uses $\$ 6$ million per year from its hotel tax to help retire bonds for the Trans World Dome, the tax also has a $\$ 4$ million annual surplus (Sutin, 2001).”

"The Massachusetts Lodging Association said that the state has a reserve of $\$ 50$ million in hotel taxes to draw on (Boston Herald Inc., 2001)." 


\section{Disadvantages}

The following points to a number of disadvantages to using a hotel tax to generate revenues for tourism:

- tourists vote with their dollars and are free to choose from a myriad of destinations;

- it is difficult to win political support for new taxes and keep them earmarked;

- sound economic policy for competing in the global marketplace does not advocate taxing exports;

- the tax structure may be unpopular with accommodation groups;

- the stifling of competitiveness through the imposition of taxes can have a significant impact on income generation and employment;

- the imposition of taxes can distort normal market operations;

- may create pricing problems for chain hotels that offer special rates across the country to key clients.

Based on the following examples it is obvious that in some cases if the tax is too high it will actually have a negative impact on the local economy. This could result in job losses and less tourist expenditures in the community. It is also important that the revenues generated from hotel taxes be spent on projects that enhance the visitor's experience in the community.

\section{Some examples}

"New York had a 20 per cent room tax which they lowered because of controversy and backlash but Houston now has the highest percent with 17 per cent on room taxes (Phoenix Newspapers Inc, 2000)."

"The Irish Hotels Federation has strongly criticized a proposal to levy a tax to fund a waste-disposal programme. Critics say that it is unfair to charge tourists for infrastructure. They say that imposing a tax would affect their tourism numbers and they want to increase tourism (Dunne \& McNally, 1998)."

"A group in the Balearic Islands off the East Coast Region would like to introduce a so-called environmental tax to be paid by tourists staying at hotels. The money raised would be spent on keeping beaches clean and projects aimed at improving the environment. The tax would add about three pounds per day to tourists staying in hotels, however, guests staying in villas will not need to pay the tax. The Majorca Hoteliers Federation is completely opposed to the tax stating that it is completely against the Maastricht Treaty, which Spain signed, that guarantees free movement of people throughout Europe. They fear that the word tax will 
encourage their current tourists to choose other vacation destinations. They also have a problem with the fact that the guests staying in villas would not need to pay the tax but they would ultimately be the ones who benefit the most from the proposed clean up (Scottish Media Newspapers Ltd, 2000)."

\section{Changing policy in Ontario}

In Ontario there are several agencies that would need to be involved in establishing a tourism levy policy. Currently municipalities in Ontario do not have the right to impose a hotel tax in their municipality. There is no supporting legislation in the Municipal Act to grant municipalities this option.

Changing this legislation requires the involvement of the Ministry of Finance, the Ministry of Tourism, Culture and Recreation and the Ministry of Municipal Affairs and Housing.

Although the Ministry of Finance has stated that one of its primary goals is to cut taxes they must recognize that communities must somehow be able to generate revenues to offset the effects of downloading by the federal and provincial governments. With the right to choose, some municipalities may decide to implement the tax and others may not, but this forces them to be accountable to their citizens and tourism stakeholders. The mission of the Ministry is to establish an environment that will sustain a dynamic, innovative and growing economy. It is doubtful that the introduction of theses taxes at the municipal level would deter tourists from visiting a community such as Timmins. The hotel tax, if properly designed and monitored, could help Timmins strive for new growth in the tourism sector and in the process help the community diversify its economy by offering first-class tourist attractions.

Within the Ministry of Tourism, Culture and Recreation, the Tourism Research and Industry Competitiveness and the Tourism Policy and Strategy branches would need to be involved in policy development. These two branches work on a number of facets regarding the industry. "The research division has developed a solid knowledge base of the industry. They conduct primary research to determine consumer's wants and needs, they conduct primary supply-side research, they monitor trends in the industry and they conduct forecasting and economic impact analysis of the tourism sector of the economy. The policy division's key mandate is to support the development of the right business climate for the tourism industry by ensuring that government policies and strategies meet the changing needs of the tourism sector, they facilitate partnerships to strengthen the industry in the province and they develop policies and strategies that enhance the overall competitiveness, growth and development of the tourism industry (OMTCR, 2001).

The Ministry of Municipal Affairs and Housing would need to work on the policy and guidelines that would enable municipalities to charge a tourism levy if they so desired. Changes would need 
to be made to the Municipal Act to permit this additional tax structure. As mentioned previously larger centres like Toronto and Ottawa have been lobbying the province to allow them to charge a hotel tax. However, at this time no enabling legislation has been introduced and no changes have been made. It is imperative that more communities demonstrate a strong case for hotel taxes to the provincial government so they can be persuaded to examine various models of taxation. They can study the feasibility of having municipal governments in Ontario making their own decisions regarding the potential implementation of a hotel tax.

Progressive communities would ensure that any hotel taxation model that would be implemented is carefully monitored. It is interesting to note that many people that were interviewed for this paper believed that the City of Toronto already charges an additional tax on accommodations yet none of them suggested that this affected their decision to visit the community. ${ }^{5}$

By giving municipal governments the power to decide, they would be directly accountable for their decision-making and would need to work in partnership with industry to make sure that the tourism goals of their communities are met. The local model is the most cost effective and easiest to implement and all the key stakeholders can share in the responsibility and decision making process.

\section{The local model}

It seems that a volunteer based levy would not work in many jurisdictions. Some of the key partners and hotels would be involved but others would remain free riders and benefit from the increased marketing and infrastructure improvements without contributing to the cause. This is something that already occurs in Timmins and creates frustration, division and unnecessary problems for the industry. The government should be involved in some capacity either by implementing legislation themselves or altering legislation to allow municipalities the authority to impose a hotel tax.

Local planning and input from the community and municipal stakeholders would also need to be emphasized. It is important that everyone has a say to determine where the money raised should be spent.

The tourism levy the City of Timmins would like to impose would be applicable to the accommodation sector. Accommodations would include any room (hotel/motel), cabin, outpost camp, cottage, bed and breakfast, which are used for lodging by the customer. This tax will not apply to accommodations furnished by non-profit charitable, educational, or religious organizations.

\footnotetext{
${ }^{5}$ Interview with Timmins Accommodations Group (TAG) committee members, May 2001.
} 
The City of Timmins would charge customers a standard levy rate of three per cent on the invoice total related to services rendered. This levy would be in addition to any federal or provincial taxes. Levies collected will be held by the hotel properties and distributed to the TEDC tourism sub-committee on a quarterly basis via a special account set-up with the assistance of the municipality. Revenues from the tourism levy would be allocated to key areas of the city's tourism strategies: (1) to assist with marketing the community as a tourist destination; and (2) to assist with future capital developments in the community.

Marketing and promotion would involve advertising, publishing and distributing pamphlets and other materials, conducting market research, or engaging in similar promotional activities that attract tourists or business travelers to the area. There should be an allowance to enable Tourism Timmins the opportunity to offset administrative expenses.

Capital developments may access some of the funding in the form of a loan to be repaid once the facility is self-sufficient; this will help pave the way for future development opportunities. A sub-committee must develop criteria to ensure that the capital projects support the needs and wants of the community's tourism target market.

The TEDC tourism subcommittee will be expected to submit a detailed annual marketing plan to the stakeholders for their review and comments. This will provide the basis for making forecasts and planning for future marketing initiatives. The emphasis should be on innovative ideas, policies and programs that show promise in revitalizing the community and region by renewing the infrastructure and creating more economic opportunities.

To simplify the process and keep costs down, every operator of a business that is subject to a room occupancy tax shall, on and after the effective date of the tax levy, assume responsibility for collecting the tax. The tax shall be stated and charged separately from the sales records and shall be paid by the purchaser to the operator of the business as trustee for and on account of the city. The tax shall be added to the sales price and shall be passed on to the purchaser instead of being borne by the operator of the business. The taxes would then be deposited into a special municipal account and the community stakeholders and the municipality who are part of the TEDC tourism subcommittee would work together to implement their marketing and capital development strategies. There would also need to be some type of penalty for a firm that does not remit the taxes to the municipality. It is also imperative that the levy can be repealed or reduced by a resolution adopted by the governing body of the city in the event that the levy creates negative repercussions in the community. 


\section{Evaluation mechanism}

There are essentially three main reasons why the municipality must conduct an annual evaluation on the proposed hotel tax: accountability, knowledge and development. These principles should always be at the forefront of the decision making process and the municipality will need to take action to make sure that the tax is not seen as a deterrent to their visitors. There must be a commitment to gather appropriate statistics and review all recommendations with the key stakeholders. By implementing this tax all stakeholders should help to determine what programs to be supported with the revenues from the hotel tax and based on feedback, they may even need to abolish the tax if the effects are negative.

The municipal government has long been faulted for its inability to provide some kind of performance measurement. Whereas the private sector uses profits as a measure of success, the public sector lacks any such performance indicator. Tax revenues may be employed to determine the effectiveness of marketing programs by keeping statistics on visitors to the area.

Furthermore, tourists should remain informed of how the tax dollars are being spent. In this way they will be able to see that the dollars are being put into projects that enhance their visit to the community. It is also important to measure both the positive and negative impacts created by the tax policy. All efforts should be made to implement recommendations brought forward. Increasingly, the public wants to know what they are getting for their tax dollars and they increasingly expect fair value. They expect the services provided to be of top quality and, therefore, first-class attractions must be created with the revenues earned though taxation.

\section{Conclusion}

The introduction of a room tax is a sound and stable business decision for the City of Timmins. By introducing the tax at the local level the City could develop a marketing program that is best suited for its target market. Room rates in Timmins are extremely competitive and in most cases are significantly lower than other major centres in Ontario. By enabling municipalities, the provincial government would not be seen as imposing new taxes and communities would be given the power to compete more effectively for tourism revenues. So far, all indications are that the inclusion of a three per cent tax levy on accommodations will not negatively impact the target market nor the clientele that now utilize the hotel/motels in Timmins. By implementing this tax at the local level, Timmins can as a community carefully monitor the impact and react quickly should the tax have any negative effects.

This model would not increase the costs for collection and it will be the first time that key stakeholders will share in the role and responsibilities of revenue expenditures. The private sector and accommodation group will have a direct link to tourism marketing and tourism capital 
projects. Based on conversations with the local accommodation providers it is obvious that they are supportive of this tax initiative but believe that legislation is needed to make sure all accommodation providers in the community participate in the program. Past experience has shown them that a voluntary system does not work well in their community. ${ }^{6}$

A 62 per cent occupancy level and given 710 rooms at $\$ 62.00$ per night, approximately $\$ 298,851.78$ in tax revenues can be expected annually. It is quite obvious that with this kind of marketing and capital project budget the community could begin to compete more effectively for tourists. With every increase in visitors, tax revenues will also increase. Timmins has many ideas on how they can capitalize on tourism; however, until a realistic and competitive base dollar budget amount is found it is doubtful that the community will ever be able to reach their tourism potential.

It is time for the provincial government to work in partnership with the local governments and grant the right to impose such a tax. This would provide municipalities with the ability to raise revenues which could then be employed to stimulate further local economic growth.

\section{Author's biography}

Christy Marinig was born and raised in Timmins, Ontario. She has a diverse educational background coupled with an extensive community volunteer portfolio. Ms. Marinig has been working with the economic development corporation for the past eight years and was promoted to the position of manager four years years ago. Ms. Marinig leads a diverse pro-active team of dedicated professionals who work in the economic development field. Her previous work experience includes the research and coordination of a major labour market study of Northeastern Ontario for the Timmins Industrial Training Advisory Committee and performing market research for the Barrie Market Research Centre.

Ms. Marinig completed a three-year Business Administration Co-Op Program from Georgian College and is currently completing a BA with a major in psychology and sciences from Laurentian University. She has also completed a number of professional development courses and has been awarded her ECD designation from the Economic Developers Association of Canada in association with the University of Waterloo.

Ms. Marinig serves in a number of volunteer capacities -, Chairperson for Northeastern Ontario Communication Networks Inc. (NEOnet), Judge for Influential Woman Awards, Steering Committee Member for Ecole Secondaire Theriault track \& field development project, Steering committee member for the strategic plan and Hollinger Park project. Ms Marinig was also appointed to serve as a Board Member for the Ontario Film Review Board.

\footnotetext{
${ }^{6}$ Interview with Timmins Accommodations Group (TAG) committee members, May 2001.
} 


\section{Bibliography}

Britannica.com, Merriam-Webster Search, Collegiate Dictionary.

City of Toronto, City Council Legislative Documents, http://www.city.toronto.on.ca/legdocs/2000/agendas/committees/bud/bud000222/it002b. htm, January 24, 2000.

Cooper, Brad, The Star Kansas co, Kansas City Star, www.traveltax.msu.edu/intro/issues/intro2.htm, March $7^{\text {th }}, 2001$.

Creamer Media. (n.d). The White Paper - The Development and Promotion of Tourism in South Africa, http://www.polity.org.za/govdocs/white_papers/tourism.html, Section 3.2.

Dunne, Jim and Frank McNally, The Irish Times, http://www.traveltax.msu.edu/news/index.htm, August $27^{\text {th }}, 1998$.

Government of South Africa Department of Environmental Affairs and Tourism, White Paper The Development and Promotion of Tourism in South Africa, http://www.polity.org.za/govdocs/white_papers/tourism.html, May, 1996.

Horsley, Lynn, The Star Kansas co., Kansas City Star, http://www.traveltax.msu.edu/news/index.htm, March 29 ${ }^{\text {th }}, 2001$.

Interview with Timmins Accommodations Group (TAG) committee members, May 2001.

Ontario Ministry of Culture Tourism and Recreation, The State of Tourism in Ontario 1999 Trends and Historical Statistics, http://www.tourism.gov.on.ca/english/index.asp, March 2001.

Ontario Ministry of Tourism, Culture and Recreation, Current Performance, http://www.tourism.gov.on.ca/english/publications/, May 2001.

Ontario Ministry of Tourism, Culture and Recreation, Historical Trends \& Statistics, http://www.tourism.gov.on.ca/english/research/pdf/may2001/historical trends.pdf., May 2001.

Ontario Ministry of Tourism, Culture and Recreation, Tourism Regional Impact Model, http://www.tourism.gov.on.ca/english/publications/, April 2001.

Ontario Ministry of Tourism Culture and Recreation, Tourism Research, http://www.tourism.gov.on.ca/english/research/, June 2001.

Ontario Ministry of Finance, http://www.gov.on.ca/FIN/english/whoeng.htm. May 2001. 
Phoenix Newspapers Inc., The Arizona Republic, http://www.traveltax.msu.edu/news/index.htm, November $3^{\text {rd }}, 2000$.

Scottish Media Newspapers Ltd., The Glasgow Herald, http://www.traveltax.msu.edu/news/index.htm, November 13, 2000.

Statistics Canada, 1999 Canadian Travel Survey, http://www.tourism.gov.on.ca/english/publications/, June 2000.

Statistics Canada, 1999 International Travel Survey, http://www.tourism.gov.on.ca/english/publications/, June 2000.

Sutin, Paul. The St-Louis Post Dispatch, http://www.traveltax.msu.edu/news/index.htm, February 17th, 2001.

The Economic Planning Group of Canada, Funding Destination Marketing with a Tourism Levy, Final Report, February, 1998.

The Boston Herald Inc., http://www.traveltax.msu.edu/news/index.htm, January 31 ${ }^{\text {st }}, 2001$.

World Travel \& Tourism Tax Policy Center, Tax Theory/Principles/Tax Issues www.traveltax.msu.edu/intro/issues/intro2.htm, May 2001. 